\title{
Research of Organic Carbon and Carbonate Content in the Bottom Sediments of the Crimean Southern Coast Shelf
}

\author{
E.I. Ovsyany, K.I. Gurov
}

Marine Hydrophysical Institute, Russian Academy of Sciences, Sevastopol, Russian Federation e-mail: gurovki@gmail.com

\begin{abstract}
Sediments on the Crimea southern coast shelf are studied within the Black Sea hygrophysical polygon in Katsiveli. Comparative analysis of the present sediments' parameters in the Crimea shelf zone is done. Physical and chemical characteristics of the bottom sediments (particle-size distribution, humidity, organic carbon content, carbonate content) are studied. The peculiarities of the sedimentation process and the specific features of spatial structure of the bottom sediment fractional composition and the organic matter content are revealed. According to the results of the study it was found that bottom sediments at the testing ground under research are represented generally by silty sands with pebbles and coquina and, to a lesser extent, by aleurite-pelitic silts. Coastal zone sediments are composed of medium sands with the inclusions of shell material and limestone gravel. Seaward part of the testing ground has the aleurite-pelitic silts. The analysis of distribution features of fine bottom sediment fractions and $\mathrm{C}_{\text {org }}$ showed that a high content of organic carbon is characteristic of fine sediments, and it is evidenced by increased carbon concentrations in the seaward part of the water area. It is shown that the organic carbon content in the bottom sediments on the Crimea southern coast shelf does not exceed the background values. This fact indicates that the existing potential anthropogenic sources (of the Limensky Gulf) of organic carbon currently don't have a significant effect on its accumulation in bottom sediments.

The areas of high carbonate concentrations coincide with the areas characterized by decreased content of fine fractions and organic carbon in the bottom sediments. Maximum values of carbonate content in Cape Kikineiz area are related to shell gravel accumulation.
\end{abstract}

Keywords: bottom sediments, Limensky Gulf, Southern coast of the Crimea, particle-size distribution, organic carbon, carbonate content.

DOI: 10.22449/1573-160X-2016-1-60-70

(C) 2016, E.I. Ovsyany, K.I. Gurov

(C) 2016, Physical Oceanography

\section{Introduction}

Bottom sediments are used as an indicator for revealing the technogenic pollution level and intensity. This is due to the fact that shelf bottom sediments (as the most important marine ecosystem element) are the final link of geochemical processes in the water - bottom system. Bottom sediments are a kind of pollution level integral indicator, inasmuch as over a long period of time they accumulate the pollutants incoming the water area. Formation intensity, particle-size and chemical compositions of bottom sediments depend on physical and geographical conditions of the basin and on the aggregation of processes running in it.

Investigations of organic carbon in bottom sediments of the Crimean Peninsula coastal water areas allowed us to estimate the effect of anthropogenic impact on the processes of organic matter accumulation in modern bottom sediments of the Crimean shelf zone [1 -6]. These investigations point out a significant role of such impact on ecologic condition of coastal water areas.

In order to assess the accumulation of organic carbon in the water areas with different levels of anthropogenic load at the Southern coast of the Crimea (SCC), 
the bottom sediments at the Black Sea hydrophysical ground (near Katsiveli village) were studied.

The testing ground is $\sim 1 \times 1.5 \mathrm{~km}$ water area, including Limensky Gulf (Blue Bay) and a stationary oceanographic platform, which is situated at $\sim 600 \mathrm{~m}$ distance from the coast (the depth of the site is $28 \mathrm{~m}$; coordinates $44^{\circ} 23^{\prime} 35^{\prime \prime} \mathrm{N}$, $\left.33^{\circ} 59^{\prime} 04^{\prime \prime} \mathrm{E}\right)$. Coastal zone in the testing ground area is composed of the Taurian Series deposits. Limensky Gulf is bounded from the East by the spurs of Mount Koshka, from the West - by Cape Kikineiz. The Gulf is stretched in the latitudinal direction and is characterized by high shores. The West coast is composed of series of clay and loam sediments with inclusions of Jurassic limestone detrital material (frequently with the size of several meters). The shores in the central part of the Gulf are steep, clayey and with an active abrasion zone. Rocky shores of the eastern part consist of the Upper Jurassic limestone blocks [7]. The Limenka River (temporary watercourse with seasonal flooding regime) discharges the Gulf in its eastern part.

The sounding, carried out in 2002, showed [8] that the bottom of the Gulf is flat and rather smooth, with $10-12^{\circ}$ slope. The average Gulf depth is about $20 \mathrm{~m}$, but the presence of large rocky boulders on the bottom characterizes its relief as a complex one. Rate of modern sediment accumulation at the SCC shelf is $40-$ $50 \mathrm{~cm} / 1000$ years. The shelf belongs to the zone of intensive substance intake to the bottom sediments $[9,10]$.

Prevailing winds are the ones of north-eastern and western directions, southern winds blow from the open sea.

\section{Research materials and methods}

Collection of materials was performed in 2012 when performing the complex hydrologic-hydrochemical research at the Black Sea hydrophysical testing ground.

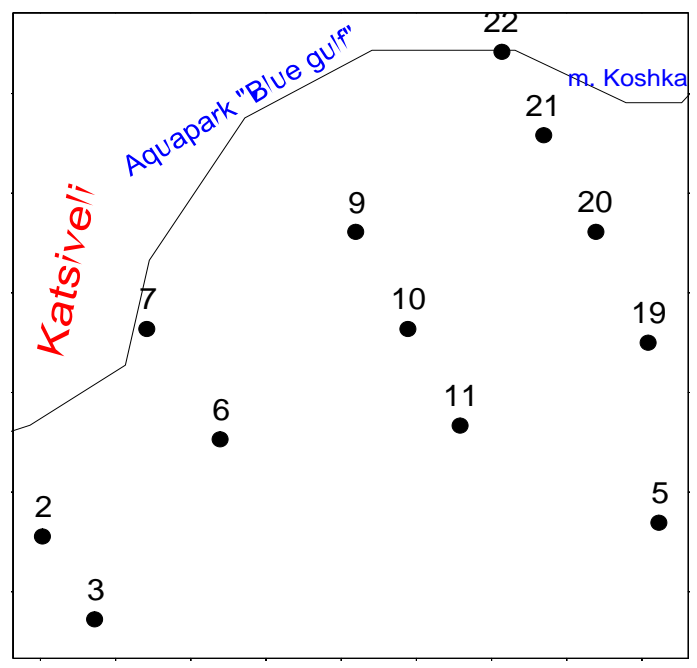

Fig. 1. The scheme of bottom sediment sampling stations at the Black Sea hydrophysical testing ground (Katsiveli village)

PHYSICAL OCEANOGRAPHY NO. 12016 
The location of stations was selected on the principle of the most complete characterization of sediment accumulation process in the conditions of complex microrelief of water area under study (Fig. 1). The sampling was performed by the grab of the Petersen dredge type, which allows us to pick the upper $5 \mathrm{~cm}$ layer of sediment mass. Particle-size distribution and chemical analysis of bottom sediments was carried out. Collection and preparation of bottom sediment samples were performed according to the normative documents [11 - 13].

T a b l e 1

General characteristics of bottom sediment surface layer $(0-5 \mathrm{~cm})$ of Limensky Gulf (SCC, Katsiveli village; sampling performed on November 28 - 30, 2012)

\begin{tabular}{|c|c|c|c|c|}
\hline Station & Depth, m & ${ }^{\circ} \mathrm{N}$ & ${ }^{\circ} \mathrm{E}$ & Characteristics of bottom sediments \\
\hline 2 & 18 & 44.391 & 33.978 & $\begin{array}{l}\text { Limestone with stone pebble }(>1 \mathrm{~mm}) \text { and } \\
\text { sand }\end{array}$ \\
\hline 3 & 41 & 44.389 & 33.979 & Dark grey silt with shells and detritus \\
\hline 5 & 39.5 & 44.391 & 33.984 & $\begin{array}{l}\text { Dark grey silt with shells ( } 20 \% \text { ) and } \\
\text { detritus }\end{array}$ \\
\hline 6 & 19.5 & 44.393 & 33.983 & Dark grey sand with shells and detritus \\
\hline 7 & 5 & 44.395 & 33.981 & Grey sand with shells and shell detritus \\
\hline 9 & 12.5 & 44.397 & 33.986 & $\begin{array}{l}\text { Dark grey gravel with sand and shell } \\
\text { detritus }\end{array}$ \\
\hline 10 & 25 & 44.395 & 33.988 & $\begin{array}{l}\text { Grey fine sand with shells }(>20 \%) \text { and } \\
\text { detritus }\end{array}$ \\
\hline 11 & 37 & 44.393 & 33.989 & Shelly gravel (>40\%) with grey liquid silt \\
\hline 19 & 38 & 44.395 & 33.994 & Dark grey silty sand with shell detritus \\
\hline 20 & 21.5 & 44.397 & 33.993 & Dark grey sand with shell detritus \\
\hline 21 & 13.5 & 44.399 & 33.991 & Grey sand with shells and shell detritus \\
\hline 22 & 7 & 44.401 & 33.990 & Dark grey sand with shells and detritus \\
\hline
\end{tabular}

Organic carbon concentration was determined by spectrophotometric method after the oxidation of sediment organic matter with the sulfochromic mixture [14, 15]. The modification of methodology with an improved technique of chemical analysis experimental part was applied. Inorganic carbon content (carbonate content) was determined by a weight-volume method after the decomposition of 62 PHYSICAL OCEANOGRAPHY NO. 12016 
sediment carbonates with the chlorohydric acid according to DSTU ISO 106932001 [16] taking into account methodological recommendations of UNEP/IOC/IAEA manual [17]. Natural moisture sediments were analyzed. Natural moisture was determined according to DSTU 11465-2001 [18]. Particle-size distribution was carried out by the standard method $[19,20]$ under the recommendations given in the papers $[17,21]$. Aleurite-pelitic fraction separation $(\leq 0.05 \mathrm{~mm})$ was performed using the wet sieving method. Coarse-grained fractions $(>0.05 \mathrm{~mm})$ were separated using the sieving method after the drying. Information on material collection and general characteristics of the Gulf bottom sediments are represented in Table 1.

\section{Results and discussion}

Grain-size distribution of bottom sediments at the testing ground. The results of study of bottom sediments at the Black Sea hydrophysical ground indicate their inhomogeneity by particle-size distribution. Bottom sediments here are represented mainly by silty sands $(0.25-0.1 \mathrm{~mm}$ fraction) with pebbles and limestone and, to a smaller extent, by aleurite-pelitic silts $(0.25-0.1 \mathrm{~mm}$ fraction) (Fig. $2-4)$. In the coastal zone, bounded by $10 \mathrm{~m}$ isobath, sediments are composed mainly of medium sands $(0.5-0.25$ fraction) with the inclusions of shell materials and limestone gravel. Testing ground seaward part has aleurite-pelitic silts. Main allochthonous components of modern sediments in the water area under study are the products of abrasion, eolian transport, Limenka river solid runoff, slope runoff. Bottom sediment autochthonous components are the products of biogenic sedimentation (limestone and shell detritus resulted from the wave reworking). The study of atmospheric aerosol at the testing ground revealed the fact that the content of detrital quartz in sediments correlates with wind activity - detrital quartz amount rises with the velocity of northern winds [22].

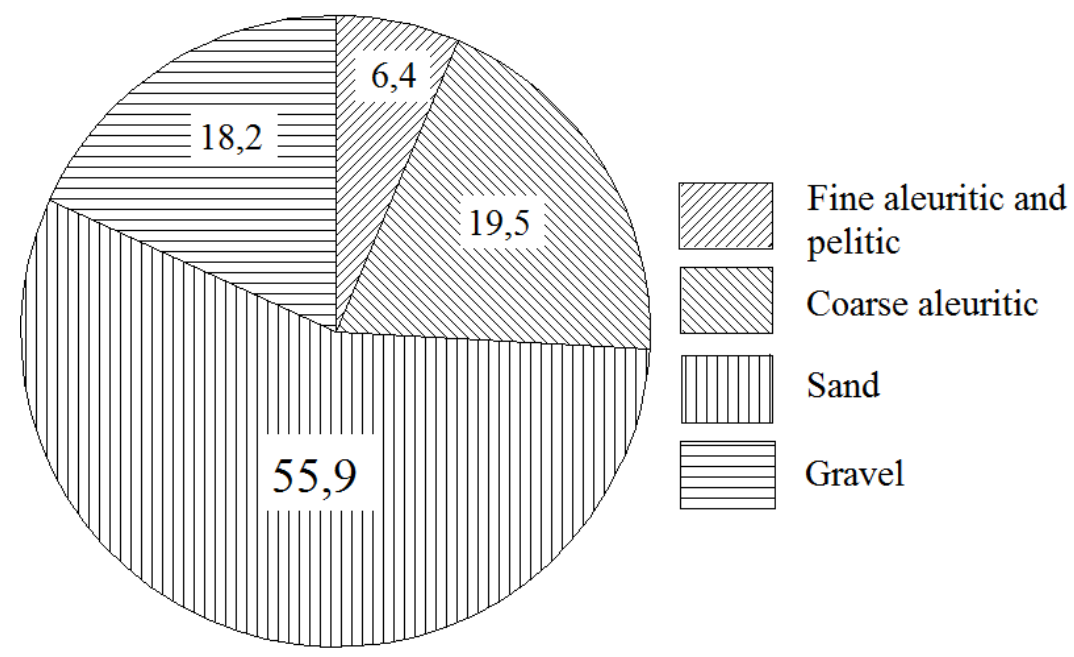

Fig. 2. Particle-size distribution of Limensky Gulf bottom sediments (percentage of fractions) 


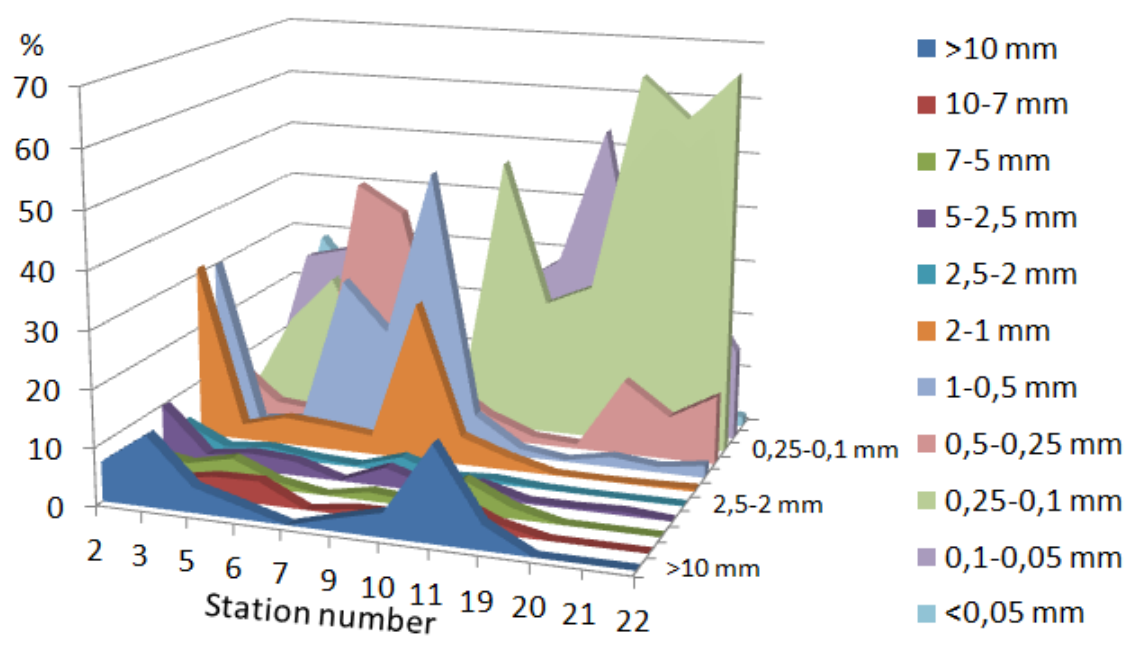

Fig. 3. Particle-size distribution of Limensky Gulf bottom sediments (the character of fraction distribution)
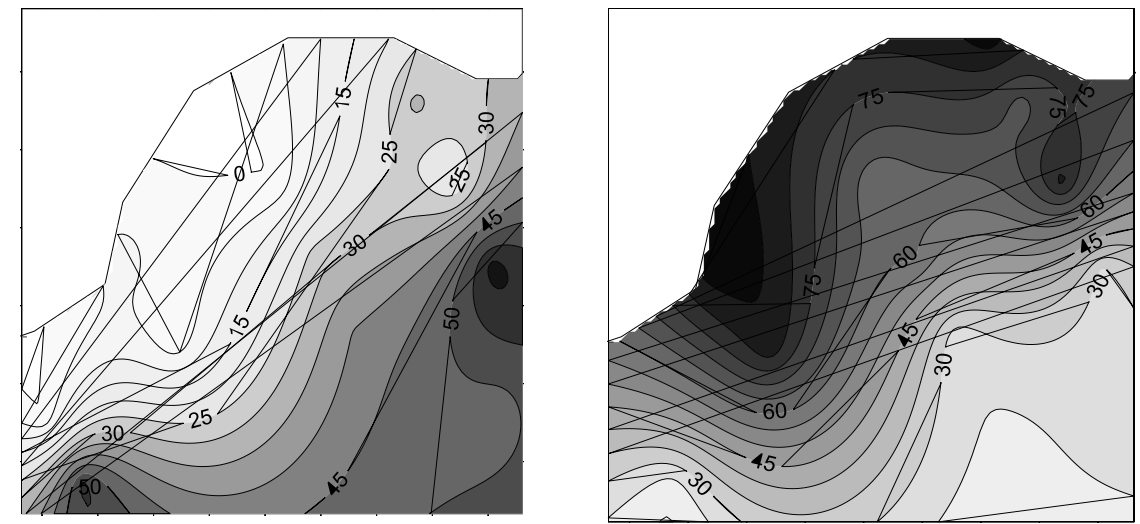

Fig. 4. Spatial distribution of aleurite-pelitic (a) and sandy $(b)$ fractions in the bottom sediment surface layer at the Black Sea hydrophysical testing ground (Katsiveli, 2012)

Silt sediments can be classified into aleurite-pelitic, pelite-aleuritic and aleuritic silts (Fig. 3, 4). Sediments with $\geq 50 \%$ content of coarse-aleuritic fraction belong to aleurite-pelitic silts, with $\geq 50 \%$ content of fine-aleuritic and pelitic fractions belong to pelite-aleuritic silts. Partitioning principles are based on the Bezrukov - Lisitsyn classification [23] amended and supplemented by Nevesskij [24] for the coastal marine sediments.

A priori it is considered that within the water area under study the anthropogenic impact sources are absent. At the same time, according to the paper [8], there are at least two permanent anthropogenic impact sources in the area under study: discharge of wastewater with a high content of suspended solids from Katsiveli village treatment plant down the ravine (Philibert watercourse) near Cape 64 
Kikineiz and Aquapark wastewaters discharge at the central part of the shore, which frames the Gulf. This part of the shore is also characterized by an active abrasion and occasional collapses of the shore composed of clayey deposits. Along with some other factors, abrasion, as a sedimentary material producer, pays a key role in the process of the Limensky Gulf bottom sediment formation. It is confirmed by the results of the Gulf suspended matter mineralogical composition study, and the main components of suspended matter are clay particles, detrital quartz grains, calcite and organic remains [22].

It was determined that two-peak diagram of fraction content, formed both by coarse and fine-grained particles, is characteristic of all sediment samples (Fig. 3). The greatest share falls on gravel (coquina and rounded limestone pebbles) and sand fractions represented by particles with $\geq 10-1 \mathrm{~mm}$ and $\leq 1-0.1 \mathrm{~mm}$, respectively. The presence of two peaks in the diagram indicates a significant heterogeneity of the Gulf bottom sediment particle-size distribution.

Aleurite-pelitic suspension (formed as a result of intensive erosion of local clayey shores and sediment surface layer wave reworking) is transported to the deep water zone. Model experiment revealed the fact that the transport of finegrained sediment part to the greater depths (in the seaward direction) occurs during the predominance of south-western winds [25].

Features of aleurite-pelitic and sand fractions distribution at the testing ground are represented in Fig. 4. As is evident from the figure, fine dispersed aleuritepelitic fractions are localized at seaward part of the testing ground.

Apparently, the most significant reason of such a high degree of bottom sediment inhomogeneity is constant changes of suspended matter sedimentation conditions determined by seasonal variations of meteorological parameters and water hydrodynamics. Obviously, the main sources of bottom sediments are suspended materials formed as a result of coast abrasion. Productive activity of benthos also makes a significant contribution. In so doing its biological role manifests itself in sedimentogenesis, and it is indicated by the presence of shell material at all stations. This process contributes to the organic matter localization and sedimentation on the bottom within the coastal areas and their further multiple usages in the food chain. Average annual sedimentation rate at the testing ground, determined by sediment trap method, makes up $0.84 \mathrm{~g} / \mathrm{cm}^{2} /$ year [26]. The results of bottom sediment accumulation measurements previously obtained by radiocarbon dating method also indicate high sediment accumulation rate in the Limensky Gulf (40 - $50 \mathrm{~cm} / 1000$ years), which is due to coast abrasion and features of hydrological regime [9].

Organic carbon and carbonate content of the Limensky Gulf bottom sediments. Total organic carbon content in marine bottom sediments is one of the main characteristics when studying geochemical aspects of sedimentation processes. In the coastal water areas exposed to anthropogenic impact the $\mathrm{C}_{\text {org }}$ content in bottom sediments is one of the of the main geochemical indicators, which characterize the marine ecosystem state $[1,2]$.

According to the data of the SCC shelf coastal zone bottom sediment organic carbon study performed by IBSS in 1970 - 1980, bottom sediments in this area were generally represented by coarse-grained fractions: sands and coquinas, rarely by silts with admixed shell detritus and silty sand. $0.91-1.14 \%$ were typical 
values characterizing $\mathrm{C}_{\text {org }}$ content (mass fraction) in silty sediments. For the sand and coquina with admixed silt they makes up $0.22-0.75 \%$. Laspi Bay bottom sediments were composed of aleuritic silts (55 - $65 \mathrm{~m}$ depth), sandy silts and sand ( $20-40 \mathrm{~m}$ depth). In the silty sediments $\mathrm{C}_{\text {org }}$ content ranged between $0.51 \%$ and $1.11 \%$, in sandy ones between $0.48 \%$ and $0.83 \%[27,28]$.

Previous investigations at the testing ground were restricted only to the study of suspended matter organic component by measuring the loss on ignition, which is not equal to the direct $\mathrm{C}_{\text {org }}$ measurements. The authors of [29] showed that the values obtained by this method didn't exceed $4 \%$ within a year (average value is $1.29 \%$ ). The data on $\mathrm{C}_{\text {org }}$ content at the shelf near the SCC, which amounted $\sim 1 \%$, are represented in [30]. According to the data of [9], $\mathrm{C}_{\text {org }}$ content in the bottom sediments for our study area on average amounted $1-2 \%$.

The results of organic matter distribution $\left(\mathrm{C}_{\text {org }}\right)$, carbonate content $\left(\mathrm{CaCO}_{3}\right)$ and the Limensky Gulf bottom sediments natural humidity $(W)$ studies, performed in 2012, are represented in Table 2. In the same table the measurements of these parameters in bottom sediments of other coastal waters of the Crimean shelf, obtained in IBSS and MHI, are contained [1 - 6, 27, 28]. Comparative analysis of these results shows that there were no sufficient changes in material composition of the SCC shelf bottom sediments over the last $40-50$ years.

In Fig. 5 the distribution of organic carbon and carbonate content in the bottom sediment surface layer at the Black Sea hydrophysical testing ground in 2012 is represented. The analysis of distribution features of bottom sediment fine fractions (Fig. 4, a) and $\mathrm{C}_{\text {org }}$ (Fig. 5, a) showed that a high content of organic carbon is characteristic of fine sediments, and it is evidenced by increased carbon concentrations in the seaward part of the water area. Such ratio is also characteristic of other water areas of the Crimean shelf: Sevastopol Bay, Gulf of Kalamita, Balaklava Bay $[1-3,5]$.
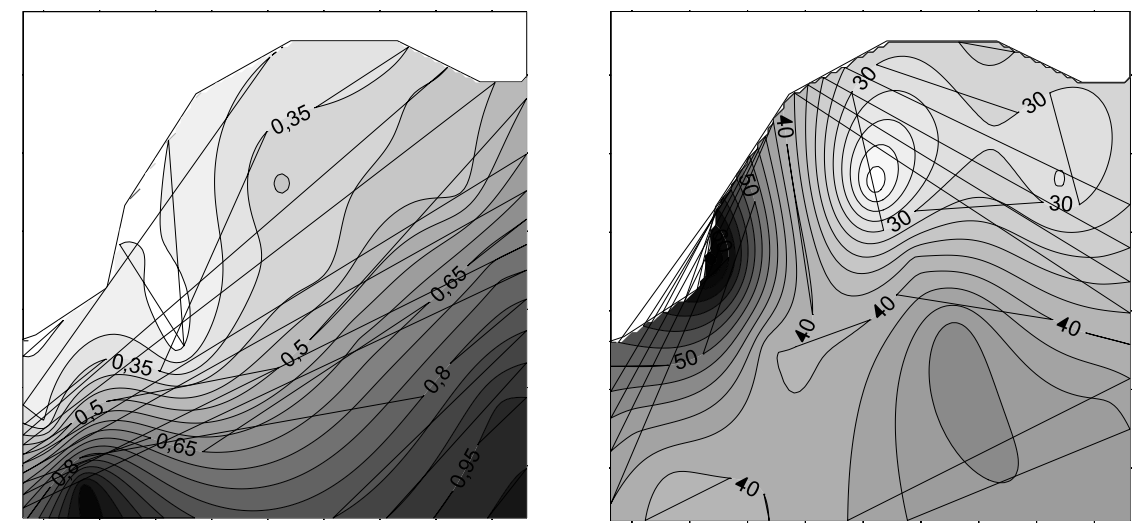

Fig. 5. Spatial distribution of organic carbon ( $a$ ) and carbonate content (b) in bottom sediment surface layer at the Black Sea hydrophysical testing ground (Katsiveli, 2012) 
Table 2

Distribution of bottom sediments organic matter $\left(\mathrm{C}_{\mathrm{org}}\right)$, carbonate content $\left(\mathrm{CaCO}_{3}\right)$ and natural humidity $(W)$ of some

Crimean shelf regions in different years

\begin{tabular}{|c|c|c|c|c|c|c|c|c|}
\hline \multirow{2}{*}{ Regions } & \multirow{2}{*}{$\begin{array}{l}\text { number of } \\
\text { stations }\end{array}$} & \multicolumn{2}{|c|}{$\mathrm{C}_{\text {org }}, \%$} & \multicolumn{2}{|c|}{$\mathrm{CaCO}_{3}, \%$} & \multicolumn{2}{|c|}{$W, \%$} & \multirow{2}{*}{ Reference } \\
\hline & & average & range & average & range & average & range & \\
\hline Limensky Gulf & 12 & 0.51 & $0.23-1.08$ & 38.8 & $20.1-47.7$ & 26.9 & $13.3-54.9$ & this paper \\
\hline Laspi Bay & 10 & 0.80 & $0.48-1.11$ & - & - & 33.5 & $25.1-47.7$ & {$[27]$} \\
\hline $\begin{array}{l}\text { Southern coast of the } \\
\text { Crimea }\end{array}$ & 26 & 0.50 & $0.16-1.14$ & - & $2.4-30.1$ & 26.5 & $20.3-30.4$ & {$[28]$} \\
\hline Sevastopol Bay & 62 & 4.38 & $0.97-11.58$ & 34.5 & $18.9-68.6$ & 46.5 & $29.9-71.3$ & {$[1,2]$} \\
\hline Balaklava Bay & 16 & 2.43 & $0.66-4.83$ & 40.1 & $18.8-82.9$ & 51.7 & $11.4-93.3$ & {$[3]$} \\
\hline Cossack Bay & 15 & 1.80 & $0.11-4.55$ & 73.7 & $44.1-96.9$ & - & - & {$[6]$} \\
\hline The Kerch Strait & 73 & 1.40 & $0.12-5.02$ & 23.6 & $2.4-91.7$ & 71.3 & $23.1-168.8$ & [4] \\
\hline $\begin{array}{l}\text { Gulf of Kalamita: } \\
\text { coastal part } \\
\text { seaward part }\end{array}$ & $\begin{array}{c}11 \\
9\end{array}$ & $\begin{array}{l}0.29 \\
0.44\end{array}$ & $\begin{array}{l}0.23-0.40 \\
0.24-0.60\end{array}$ & $\begin{array}{l}53.1 \\
42.0\end{array}$ & $\begin{array}{l}22.3-97.0 \\
19.6-96.7\end{array}$ & $\begin{array}{c}35.7 \\
46\end{array}$ & $\begin{array}{l}24.7-59.6 \\
29.0-62.0\end{array}$ & [5] \\
\hline Gulf of Kalamita & 17 & 0.14 & $0.06-0.62$ & - & - & 27.7 & $20.3-30.4$ & [27] \\
\hline
\end{tabular}

PHYSICAL OCEANOGRAPHY NO. 12016 
Maximum values of carbonate content in Cape Kikineiz area are related to shell gravel accumulation (stations 2, 3, 6, 7). The areas of high carbonate concentrations coincide with the areas characterized by decreased content of fine fractions and organic carbon in the bottom sediments (Fig. 4, $a$, Fig. 5, $a, b$ ). The analysis of these results and the earlier obtained data on the study of organic carbon in the bottom sediments of the Crimean shelf coastal water areas (Table 2) [1 - 6, $27,28]$ allows us to assert that the current level of organic matter accumulation in the Limensky Gulf is relatively insignificant and does not exceed the previously submitted assessments [10, 30].

In comparison with anthropogenically loaded water areas both with limited water exchange (the bays of Sevastopol: Cossack Bay, Balaklava Bay, Sevastopol Bay) and open one (Gulf of Kalamita, the Kerch Strait) average $\mathrm{C}_{\text {org }}$ content in the SCC water area under research is significantly lower and does not exceed the background values (they are close to the values of organic carbon content in the Black Sea bottom sediments) [31]. This fact indicates that the existing potential anthropogenic sources of organic carbon currently don't have a significant effect on its accumulation in bottom sediments.

\section{Conclusion}

According to the results of the study it was found that bottom sediments at the testing ground under research are represented generally by silty sands with pebbles and coquina and, to a lesser extent, by aleurite-pelitic silts. Coastal zone sediments are composed of medium sands with the inclusions of shell material and limestone gravel. Seaward part of the testing ground has the aleurite-pelitic silts.

The reason of such a high degree of bottom sediment inhomogeneity is constant changes of suspended matter sedimentation conditions determined by seasonal variations of meteorological parameters and water hydrodynamics. Obviously, the main sources of bottom sediments are suspended materials formed as a result of coast abrasion.

The analysis of distribution features of fine bottom sediment fractions and $\mathrm{C}_{\text {org }}$ showed that a high content of organic carbon is characteristic of fine sediments, and it is evidenced by increased carbon concentrations in the seaward part of the water area.

The areas of high carbonate concentrations coincide with the areas characterized by decreased content of fine fractions and organic carbon in the bottom sediments. Maximum values of carbonate content in Cape Kikineiz area are related to shell gravel accumulation. $\mathrm{C}_{\text {org }}$ content level at the SCC shelf (the Black Sea hydrophysical testing ground, Katsiveli) does not exceed the background values and is sufficiently lower than the values characteristic of anthropogenically loaded water areas both with limited water exchange (the bays of Sevastopol: Cossack Bay, Balaklava Bay, Sevastopol Bay) and open one (Gulf of Kalamita, the Kerch Strait). This fact indicates that the existing potential anthropogenic sources (of the Limensky Gulf) of organic carbon currently don't have a significant effect on its accumulation in bottom sediments.

\section{REFERENCES}

1. Osadchaya, T.S., Ovsyaniy, E.I. \& Kemp, R. [et al.], 2003, “Organic carbon and oil hydrocarbons in bottom sediments of Sevastopol bay (the Black Sea)”, Mar. ecol. J., V. II, no. 2, pp. 94-101. 
2. Ignat'eva, O.G., Ovsyanyy, E.I. \& Romanov, A.S. [et al.], 2008, “Karbonatnaya sistema vod i soderzhanie organicheskogo ugleroda $v$ donnykh osadkakh Sevastopol'skoy bukhty (Chernoe more) po dannym nablyudeniy s 1998 po 2005 gody [Carbonate water system and organic carbon content in the bottom sediments of Sevastopol Bay (the Black Sea)] according to observational data from 1998 to 2005]”, Morskoy gidrofizicheskiy zhurnal, no. 2, pp. 57-67 (in Russian).

3. Ovsyanyy, E.I., Kotel'yanets, E.A. \& Orekhova, N.A., 2009, "Mysh'yak i tyazhelye metally v donnykh otlozheniyakh Balaklavskoy bukhty (Chernoe more) [Arsenic and heavy metals in the bottom sediments of Balaklava Bay (the Black Sea)], Morskoy gidrofizicheskiy zhurnal, no. 4, pp. 67-80 (in Russian).

4. Ovsyanyy, E.I., Konovalov, S.K., Mitropol'skiy, A.Yu. [et al.], 2015, “Organicheskiy uglerod i karbonatnost' sovremennykh donnykh otlozheniy Kerchenskogo proliva [Organic carbon and carbonate content of modern bottom sediments of the Kerch Strait”, Geokhimiya, no. 12, pp. 1-12 (in Russian).

5. Gurov, K.I., Konovalov, S.K. \& Ovsyanyy, E.I., 2014, "Geokhimicheskie kharakteristiki donnykh otlozheniy akvatorii Kalamitskogo zaliva Chernogo morya [Geochemical characteristics of bottom sediments of the Black Sea Kalamitsky Gulf waters]”, Morskoy gidrofizicheskiy zhurnal, no. 5, pp. 69-80 (in Russian).

6. Romanov, A.S., Orekhova, N.A. \& Ignat'eva, O.G. [et al.], 2007, "Vliyanie fizikokhimicheskikh kharakteristik donnykh osadkov na raspredelenie mikroelementov na primere bukht Sevastopolya (Chernoe more) [Influence of physico-chemical characteristics of the bottom sediments on the trace elements' distribution by the example of Sevastopol bays (the Black Sea)”, Ekologiya morya, iss. 73, pp. 85-90 (in Russian).

7. Shestopalov, V.M., Ivanov, V.A. \& Boguslavskiy, S.G. [et al.], 2005, "Inzhenernogeologicheskie opasnosti beregovoy zony Gornogo Kryma [Engineering and geological hazards of the Mountainous Crimea coastal zone]", Ekologicheskaya bezopasnost' pribrezhnoy i shel'fovoy zon i kompleksnoe ispol'zovanie resursov shel'fa, iss. 13, pp. 119-131 (in Russian).

8. Kondrat'ev, S.I., Lisichenok, A.D. \& Lyashenko, S.V. [et al.], 2003, Gidrologogidrokhimicheskie i gidroopticheskie kharakteristiki vod Golubogo zaliva (pos. Katsiveli, sentyabr' 2002 g.) [Hydrologic-hydrochemical and hydrooptical characteristics of Blue Bay waters (Katsiveli, September 2002)]”, Ekologicheskaya bezopasnost' pribrezhnoy i shel'fovoy zon i kompleksnoe ispol'zovanie resursov shel'fa, iss. 8, pp. 119-131 (in Russian).

9. $\quad$ Shnyukov, E.F., Ogorodnikov, V.I. \& Kovalyukh, N.N. [et al.], 1984, “Sovremennye osadki i skorosti osadkonakopleniya $v$ golotsene na chernomorskom shel'fe USSR [Recent sediments and sedimentation rates in the Holocene on the Black Sea shelf of the USSR]", Tr. Mezhdunar. simpoz., part. 1, Kiev, Naukova dumka, pp. 122-130 (in Russian).

10. 1985, “Geologiya shel'fa USSR. Litologiya.”, Kiev, Naukova dumka, 189 p. (in Russian).

11. 1984, GOST 17.1.5.01-80., "Okhrana prirody. Gidrosfera. Obshchie trebovaniya k otboru prob donnykh otlozheniy vodnykh ob"ektov dlya analiza na zagryaznennost'”, Gosstandart, 5 p. (in Russian).

12. 2002, DSTU ISO 5667-12:2001, "Kachestvo vody. Otbor prob. Ch. 12. Rukovodstvo po otboru prob donnykh osadkov (ISO 5667-12:1995, IDT)”, Kiev, Derzhstandart Ukrainy, 31 p. (in Russian).

13. 2002, DSTU ISO 5667-19:2009, "Kachestvo vody. Otbor prob. CH. 19. Metodicheskie ukazaniya po otboru prob morskikh otlozheniy (ISO 5667-19:2004, IDT)”, Kiev, Derzhspozhivstandart Ukrainy, 11 p. (in Russian).

14. 2002, DSTU ISO 14235-2005, "Kachestvo grunta. Opredelenie organicheskogo ugleroda sul'fokhromnym okisleniem (ISO 14235-1998, IDT)”, Kiev, Derzhspozhivstandart Ukrainy, 7 p. (in Russian).

15. 2002, DSTU 4289:2004, “Kachestvo grunta. Metody opredeleniya organicheskogo veshchestva”, Kiev, Derzhspozhivstandart Ukrainy, 9 p. (in Russian).

16. 2002, DSTU ISO 10693-2001, "Kachestvo grunta. Opredelenie soderzhaniya karbonatov. Ob"emnyy metod (ISO 10693:1995, IDT)”, Kiev, Derzhspozhivstandart Ukrainy, 8 p. (in Russian).

PHYSICAL OCEANOGRAPHY NO. 12016 
17. 1995, UNEP/IOC/IAEA, "Manual for the geochemical analyses of marine sediments and suspended particulate matter”, UNEP, no. 63, $74 \mathrm{p}$.

18. 2002, DSTU ISO 11465-2001, "Kachestvo grunta. Opredelenie sukhogo veshchestva i vlazhnosti po masse. Gravimetricheskiy metod (ISO 11465:1993, IDT)”, Kiev, Derzhspozhivstandart Ukrainy, 5 p. (in Russian).

19. 2006, DSTU ISO 11277:2005, "Kachestvo grunta. Opredelenie granulometricheskogo sostava i mineral'nogo materiala grunta. Metod proseivaniya i sedimentatsii (ISO 11277:1998, IDT)”, Kiev, Derzhspozhivstandart Ukrainy, 29 p. (in Russian).

20. 1988, GOST 12536-79, "Grunty. Metody laboratornogo opredeleniya granulometricheskogo (zernovogo) i mikroagregatnogo sostava”, Izd-vo standartov, 22 p. (in Russian).

21. Petelin, V.P., 1967, "Granulometricheskiy analiz morskikh donnykh osadkov", Moscow, Nauka, 128 p. (in Russian).

22. Nasedkin, E.I., Kuznetsov, A.S. \& TSikhotskaya, N.N. [et al.], 2005, “Monitoring sezonnykh izmeneniy mineral'nogo sostava vzveshennogo veshchestva osadkonakopleniya [Seasonal change monitoring of suspended matter sedimentation mineral composition]", Ekologicheskaya bezopasnost' pribrezhnoy i shel'fovoy zon i kompleksnoe ispol'zovanie resursov shel'fa, iss. 12, pp. 236-241 (in Russian).

23. Bezrukov, P.L., Lisitsyn, A.P., 1960, "Klassifikatsiya osadkov sovremennykh morskikh vodoemov [Classification of sediments of modern water bodies]", Tr. In-ta okeanologii AN SSSR, 32, pp. 3-14 (in Russian).

24. Nevesskiy, E.N., 1967, "Protsessy osadkoobrazovaniya v pribrezhnoy zone morya”, Moscow, Nauka, 255 p. (in Russian).

25. Alekseev, D.V., 2013, “Modelirovanie transporta donnykh osadkov v rayone Golubogo zaliva Chernogo morya [Modeling of bottom sediment transport in Blue Bay region of the Black Sea]", Dop. NAN Ukraini, no. 13, pp. 94-100 (in Russian).

26. Mitropol'skiy, O.Yu., Nasedkin, E.I., Stepanyak, Yu.D. [et al.], 2005, “Kompleksniy geoekologichniy monitoring shel'fu - neobkhidna umova dostovirnoï otsinki suchasnogo stanu mors'kikh ekosistem [Comprehensive environmental monitoring of the shelf: a necessary condition for accurate assessment of the current state of marine ecosystems]", Ekologicheskaya bezopasnost' pribrezhnoy i shel'fovoy zon i kompleksnoe ispol'zovanie resursov shel'fa, iss. 13, pp. 111-116 (in Russian).

27. Mironov, O.G., Kiryukhina, L.N. \& Divavin, I.A., 1992, "Sanitarno-biologicheskie issledovaniya v Chernom more”, SPb, Gidrometeoizdat, 115 p. (in Russian).

28. Kiryukhina, L.N., 1992, "Fiziko-khimicheskaya kharakteristika donnykh osadkov: donnye osadki filofornogo polya Zernova, Kalamitskogo zaliva, krymskogo shel'fa [Physico-chemical characteristics of Zernov phylophora field, Kalamitsky Gulf and the Crimean shelf bottom sediments]”, Molismologiya Chernogo morya, Kiev, Naukova dumka, pp. 222-230 (in Russian).

29. Nasedkin, E.I., Ivanova, A.N. \& Kuznetsov, A.S. [et al.], 2009, “Nekotorye rezul'taty issledovaniy vliyaniya meteorologicheskikh faktorov na protsessy sovremennogo osadkonakopleniya [Several results of study of meteorological factors impact on the sedimentation processes]", Ekologicheskaya bezopasnost' pribrezhnoy $i$ shel'fovoy zon $i$ kompleksnoe ispol'zovanie resursov shel'fa, iss. 19, pp. $44-55$ (in Russian).

30. Sorokin, V.M., Kuprin, P.N. \& Luksha, V.L. [et al.], 1984, "Sostav i usloviya formirovaniya pozdnechetvertichnykh osadkov zapadnoy chasti Chernogo morya [Composition and conditions of late Quaternary sediments formation in the western part of the Black Sea]", Izuchenie geologicheskoy istorii i protsessov sovremennogo osadkoobrazovaniya Chernogo i Baltiyskogo morey, Tr. Mezhdunar. simpoz., part 1, Kiev, Naukova dumka, pp. 89-95 (in Russian).

31. Mitropol'skiy, A.Yu., Bezborodov, A.A. \& Ovsyanyy, E.I., 1982, "Geokhimiya Chernogo morya”, Kiev, Naukova dumka, 143 p. (in Russian). 